\title{
Economic Value of Ecosystem Services, Minerals and Oil in a Melting Arctic: a Preliminary Assessment
}

\author{
Tanya O’Garra ${ }^{1}$ \\ Center for Research on Environmental Decisions, Columbia University, Schermerhorn Hall, \\ New York 10027, U.S.
}

\begin{abstract}
The Arctic region is composed of unique marine and terrestrial ecosystems that provide a range of services to local and global populations. However, Arctic sea-ice is melting at an unprecedented rate, threatening many of these ecosystems and the services they provide. This short communication provides a preliminary assessment of the quantity, distribution and economic value of key ecosystem services as well as geological resources such as oil and minerals provided by Arctic ecosystems to beneficiaries in the Arctic region and globally. Using biophysical and economic data from existing studies, preliminary estimates indicate that the Arctic currently provides about $\$ 290$ billion per year (in 2016 US\$) in terms of food, mineral extraction, oil production, tourism, hunting, existence values and climate regulation. However, given predictions of ice-free summers by 2037, many of the ecosystem services may be lost. We hope that this communication stimulates discussion among policy-makers regarding the value of ecosystem services and such geological resources as minerals and oil provided by the Arctic region, and the potential ecosystem losses resulting from Arctic melt, so as to motivate decisions vis a vis climate change mitigation before Arctic ice disappears completely.
\end{abstract}

Keywords: Arctic; valuation; ecosystem; climate change

\footnotetext{
${ }^{1}$ Present address: Middlesex University, Department of Economics, The Burroughs, Williams Building, London NW4 4BT. Email: tanyaogarra@gmail.com
} 


\section{Introduction}

Although often perceived as barren and devoid of life, the Arctic region (Figure 1) is composed of unique marine and terrestrial ecosystems and abiotic natural resources, such as minerals and oil, that provide a range of services to both local and global populations (Barros et al., 2014; CAFF, 2013). Local communities benefit from access to subsistence goods, such as fish, birds and marine mammals, and obtain significant cultural benefits from collectively engaging in subsistence hunting and interacting with their landscapes (CAFF, 2013). Non-Arctic communities around the world benefit indirectly from aesthetic services provided by the Arctic environment (e.g. documentary and photography) and knowledge generated by research in the region; they also benefit directly from recreational opportunities in the Arctic. And the wellbeing of the entire global community is dependent on climate regulation services provided by Arctic sea-ice and land-based permafrost (Goodstein et al, 2010).

\section{Figure 1. The Arctic Circle}

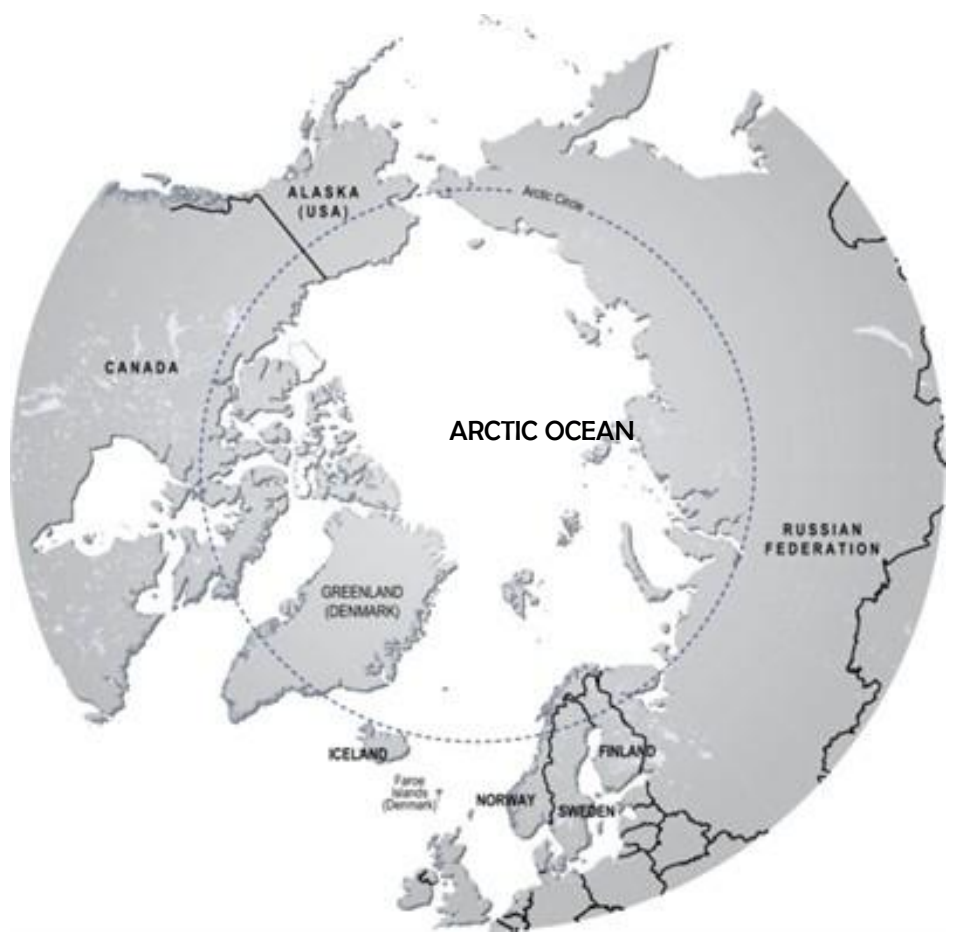

Courtesy of Hugo Ahlenius, UNEP/GRID-Arendal

http://www.grida.no/graphicslib/detail/arctic-map-political_1547. 
However, the Arctic region is experiencing rapid climate change. Permafrost (permanently frozen subsoil) on Arctic land areas is melting, sea temperatures are rising, and the Arctic sea is predicted to be completely ice-free in summer before mid-century (Figure 2) (Program, 2014; IPCC, 2013; Wang and Overland, 2009).

Declining sea-ice, warmer temperatures, and longer summer periods have serious implications for the health of Arctic ecosystems and the well-being of local and global communities. Sea-ice decline will result in decreasing availability of sea-ice algae, which contributes about 57 percent of Arctic marine primary production (Gosselin et al., 1997). Sea-ice dependent species, such as polar bears, are already experiencing declines as their usual hunting grounds disappear (Durner et al., 2009). Warmer sea-temperatures may lead to declines in marine species that depend on cooler Arctic waters for survival (e.g. Arctic cod) (Vilhjálmsson \& Hoel, 2013). These ecosystem impacts directly affect local communities that depend on their surrounding environment for subsistence, income generation and cultural identity. The loss of unique ecosystems and species may also represent a loss to people around the world who value them for their own sake independent of use; moreover, some would argue that these ecosystems have intrinsic value independent of human preferences (Turner, 2001).

Figure 2. Current and projected Arctic sea ice extent

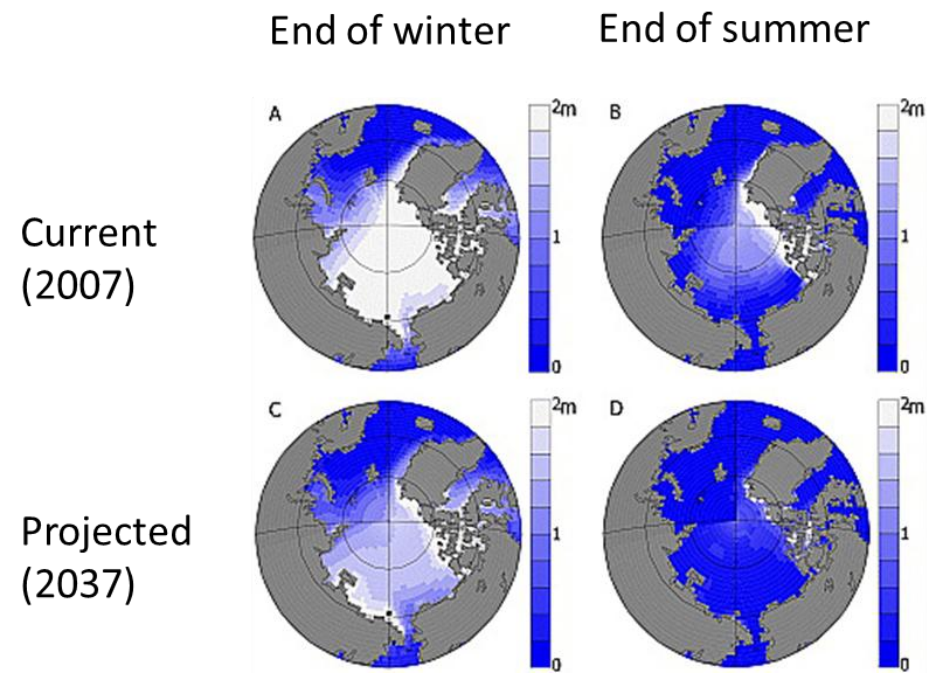

Source: Wang \& Overland (2009) 
Climate change impacts on the Arctic will also have physical consequences at a global scale. As permafrost melts, methane is released from the newly exposed soil thereby increasing the concentration of greenhouse gases in the atmosphere (Goodstein et al., 2010). In addition, the ice-albedo effect is diminishing as retreating sea-ice means less sunlight is being reflected back into space. Both these effects imply the loss of important climate regulation services provided by the Arctic, which will lead to even greater warming of the atmosphere (Goodstein et al., 2010). Given the rapid changes that are taking place in the Arctic, it is critical to account for the value of the services provided to society by Arctic ecosystems and the potential costs resulting from their loss (de Groot et al., 2012). This will allow for more informed decision-making regarding protection and conservation efforts, and estimation of compensation for local communities suffering the brunt of these losses. This study provides a preliminary assessment of the quantity, distribution and economic value of key goods and services currently provided by Arctic ecosystems. Benefits will be assessed for different beneficiaries including local communities, populations of Arctic nations, industries benefitting from ecosystem services, minerals and oil in the Arctic, and the international community. Notably, the Arctic biome is composed of more than one ecosystem. These may be broadly classed as: 1) terrestrial (tundra, boreal forests and permafrost), 2) marine, and 3) sea-ice. For the purpose of this study, only goods and services that are delivered by ecosystems or mineral and oil resources north of the Arctic Circle ( $66^{\circ}$ latitude) will be considered, unless otherwise stated.

It is noted that, although ES valuation does not typically include abiotic resources (see for e.g. MA, 2005), such as minerals and oil, it was considered appropriate to include them in the present study due to the importance of these resources to management, businesses and local communities (AMAP, 2010). As noted by van der Meulen, Braat \& Brils (2016), leaving out abiotic flows with high societal relevance from analyses of ES fails to account for competing interests between use of abiotic resources and use or management of biotic resources. This issue of how to account for abiotic resources in ES valuation is also discussed in Armstrong et al (2012) and Daly (2015). However, it is acknowledged that the environmental impacts of extracting minerals and oil may not be fully accounted for in the present study, which uses only the costs of production, although to a certain extent, investments in civil liability funds set aside for mitigation and remediation 
purposes should be reflected in the costs of production (Mason, 2003). The implications of the environmental impacts of extractive (as well as non-extractive) direct uses of the Arctic natural resources will be discussed alongside the discussion of the benefits of extraction.

Economic values reported here have been sourced from secondary sources, combined with a few original calculations (detailed in Section 4). Values are structured using the 'total economic valuation' framework, which accounts for the full range of benefits provided by ecosystems as well as minerals and oil, in an attempt to understand the annual economic value of the benefits currently provided by the Arctic.

\section{Total Economic Valuation Framework}

From an economic point of view, the flow of benefits provided by ecosystems, minerals and oil have economic value in as much as they satisfy human preferences, needs and wants. This does not mean they do not have intrinsic value that is independent of human preferences, but economics relies on humans for valuations to be made (for a discussion on the anthropocentric assumptions underlying economic valuation, see Turner (2001)). The economic value of an ecosystem is generated by the combination of services provided by the ecosystem, which include regulating (e.g. climate regulation), provisioning (e.g. food) and cultural services (Pascual et al.. 2010; Hein et al., 2006), in conjunction with investments of effort, time and other forms of human-derived capital (Braat \& de Groot, 2012; Jones et al, 2016). The aggregate economic value of these ecosystem services (ES) may be divided into several components (Krutilla, 1967), which are summarized in Figure 3. These values make up the Total Economic Value (TEV) of an ecosystem. In assessing the TEV of an ecosystem, it is advisable to focus on the final products (e.g. provisioning services such as food) to avoid double-counting (Hein et al., 2006). For more detailed discussion on the use of the TEV to value ES, see Pascual et al. (2010). 
Figure 3. Total economic value framework for the Arctic

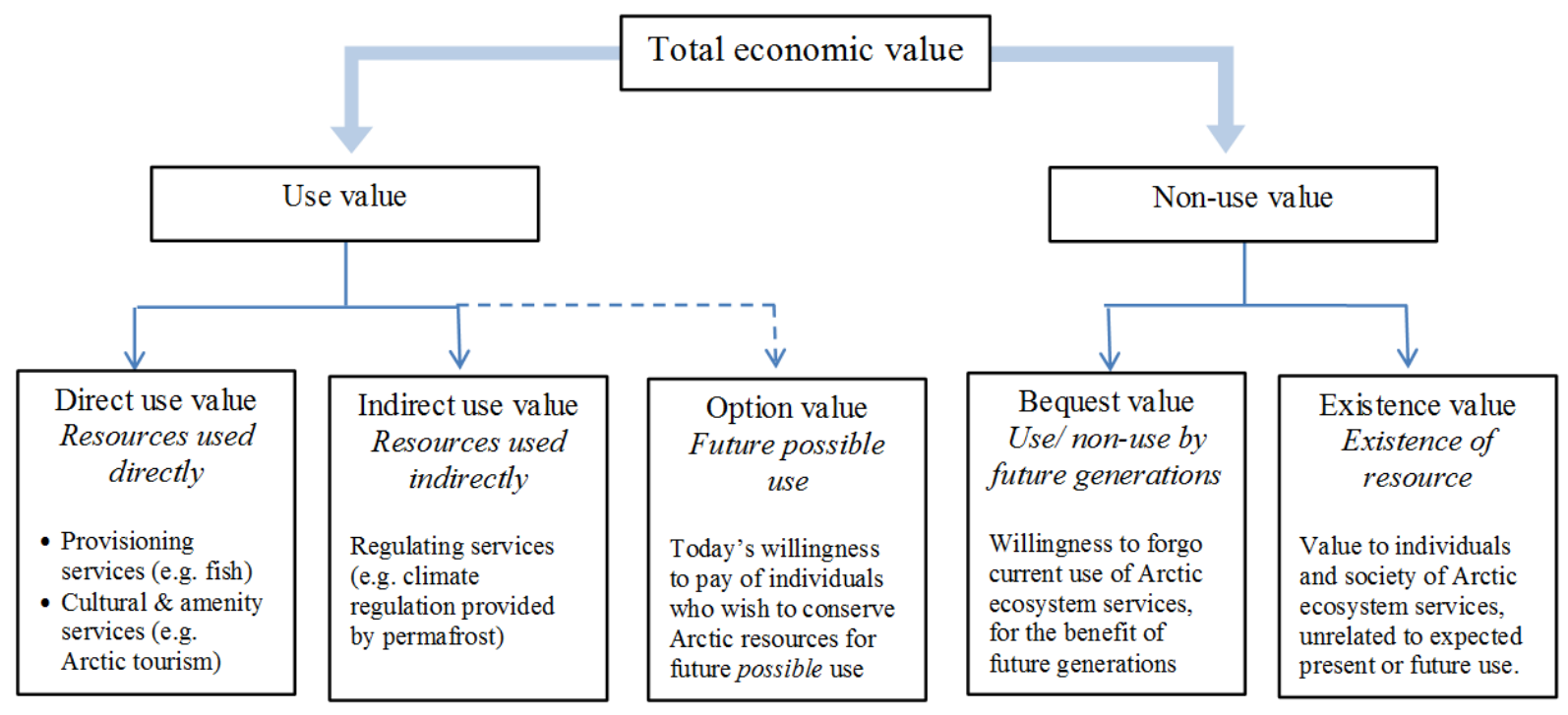

Using the TEV framework, the present study aims to estimate the economic value of the goods and services provided by Arctic ecosystems as well as by minerals and oil (see Section 3) to beneficiaries within the Arctic region and globally.

\section{Selection of ecosystem services, minerals and oil resources for valuation}

The key services that are included in this study (Table 1) were selected in discussion with experts on Arctic science at Columbia University (members of the NSF-funded PoLAR project) in combination with a review of key documents on Arctic biodiversity, mineral and fossil fuel resources and potential impacts of climate change in the region (e.g. CAFF, 2013; Hassol, 2013). The final list is far from exhaustive, and excludes important values for which there is insufficient data available, such as tourism expenditures on land, values associated with sport hunting, and existence and bequest values for the Arctic as a whole. However, it is hoped that the preliminary 
estimates provided in this study capture the value of some of the more important resources provided within the region.

\section{Data Collection and Methods}

This study uses data from secondary sources, and a few original calculations. Given the dearth of peer-reviewed publications on the value of Arctic ecosystems (noted in Costanza et al., 1997 and later in de Groot et al., 2012) identified in relevant journals, such as Ecological Economics and Environmental and Resource Economics, as well as valuation databases such as such as EVRI (1997) and ValueBaseSwe (Sundberg and Soderqvist, 2007), existing studies were also sourced from the grey literature, and governmental and consultancy reports. Existing studies use a variety of methods to value resources, depending on the ecosystem service or other natural resource being valued. Direct use values were estimated using market prices \&/or replacement cost approaches; indirect use values were assessed using damage cost approaches; and non-use values were mostly assessed using stated preference methods, or benefits transfer. For a review of these methods, see Pearce et al. (2006).

With the exception of the existence value of polar bears conducted by Olar et al. (2011), all values reported this this paper are based on data from original case studies. The value of polar bears reported in Olar et al. (2011) was produced using a model generated by Richardson and Loomis (2009) based on a meta-analysis of contingent valuation studies of endangered species (none of which included the polar bear). It was considered important to include the existence value of polar bears given the iconic importance of this species, and its role as a keystone species in the Arctic (Duarte et al., 2012). Additionally, only ecosystem services or abiotic resources generated within the Arctic region were included; however, existence values for beluga whales used values estimated for belugas in the St Lawrence Estuary which is south of the Arctic circle (Boxall et al., 2012). However, beluga whales tend to migrate between Arctic and sub-Arctic waters (Laidre, 2008), so the willingness to pay (WTP) for the more southerly beluga was taken as indicative of WTP for belugas in general.

The benefits from Arctic ES accrue to different beneficiaries, depending on the scales at which they are provided and at which the benefits are realized (Hein et al., 2006). The different 
beneficiary groups considered in this paper include: a) local communities living in the Arctic region, b) the wider populations of Arctic nations (Alaska (U.S.), Finland, Greenland (Denmark), Iceland, Norway, Russia and Sweden), c) private industry with interests in the Arctic (i.e. fishing, mining, oil and tourism), and d) the international community. Local communities in the Arctic engage directly with their local ecosystems and landscapes through the harvest of local resources (provisioning services); indigenous communities in particular obtain significant cultural benefits from cooperating on hunting activities (Huntington, 2013). Cultural benefits may also be enjoyed by national and international communities; for example, conservation of unique species such as the polar bear may be valued by citizens of Arctic countries as well as by the international community. Industries in the region benefit from the large-scale provision of fisheries, minerals and oil benefits (in conjunction with human-capital inputs benefits). Climate regulation services benefit local, national Arctic and international communities via the stabilization of the climate, which impacts growing seasons, species distributions, flooding, droughts and so forth (IPCC, 2007). In fact, a large proportion of the associated final services from climate regulation (see Section 4) accrue to communities outside of the Arctic region. Thus, although climate regulation contributes to the production of some of the final services included in this study, a large part involves benefits to the rest of the world. For this reason, climate regulation is included in this study; however, to avoid double-counting it has been assumed that climate regulation is fully accounted for in the value of the following final goods: food (subsistence harvest and commercial fisheries), polar bear hunting, and the existence value of reindeer herding, beluga whales and polar bears. Thus, the full economic value of these final services has been deducted from the climate regulation value. For more details, see Supplementary Material.

All values were converted (where necessary) to per capita annual values (i.e. the benefit per person per year), and are standardized to 2016 US\$, using inflation rates and purchasing power parity conversion factors as appropriate. The full description of data sources, procedures and assumptions used to obtain estimates of the economic value of key Arctic ES and abiotic resources in this study are found in the Supplementary Material. 


\section{Results}

Economic values for key goods and services provided by ecosystems, as well as minerals and oil resources, in the Arctic region are presented in Table 1 below. In addition to point estimates, value ranges are also provided where this information is available. Results show that there is more available data associated with direct (extractive) use values, than for any of the other subcategories of economic value. This does not reflect their relative importance, but the fact that they are easier to measure due to the availability of data on prices and quantities harvested/extracted. The data for direct-use extractive values suggest that oil resources have the greatest economic value (US $\$ 17.45 \mathrm{bn}$ annually) followed by mineral extraction (US $\$ 2.35 \mathrm{bn}$ per year) and arctic fisheries (US\$1.26bn per year).

Subsistence-based extraction, on the other hand, accounts for a far smaller $\$ 0.25 \mathrm{bn}$ per year in value. However, the population benefitting from subsistence activities is very small (about 400,000 people (Bogoyavlenskiy \& Siggner, 2004)), so the distribution of these benefits results in a substantial US\$633 per capita per year. Given an average per capita income in the Arctic region of about US\$21,000 per year (Larsen \& Fondahl, 2015), subsistence use-values represent three percent of per capita income. This figure however does not include the cultural and social capital (i.e. trust and social network) benefits from engaging in subsistence activities, which are likely to be significant (Huntington, 2013). 
Table 1. Summary of Annual Economic Values of Key Arctic Ecosystem Services, Minerals and Oil

\begin{tabular}{|c|c|c|c|c|c|}
\hline & Details & Ecosystem & $\begin{array}{l}\text { Annual value } \\
\text { (billions } 2016 \text { US\$) }\end{array}$ & Whose benefits? & $\begin{array}{l}\text { Annual value per } \\
\text { capita (2016 US\$) }\end{array}$ \\
\hline \multicolumn{6}{|c|}{ Direct use value (extractive/provisioning) } \\
\hline $\begin{array}{l}\text { Food (subsistence } \\
\text { harvest) }\end{array}$ & $\begin{array}{l}\text { Fish, land mammals, marine } \\
\text { mammals, birds, eggs, plants }\end{array}$ & $\mathrm{T}, \mathrm{M}, \mathrm{S}$ & $\begin{array}{c}0.25 \\
(0.17-0.33)\end{array}$ & Local indigenous ( $\mathrm{n}=$ approx. 400,000 ) & $\begin{array}{c}633 \\
(421-843)\end{array}$ \\
\hline $\begin{array}{l}\text { Food (commercial } \\
\text { fisheries) }\end{array}$ & e.g. Arctic cod, groundfish, salmon. & M & 1.26 & Fisheries producers & $\mathrm{n} / \mathrm{d}$ \\
\hline Minerals & $\begin{array}{l}\text { e.g. Zinc, chromium, lead, gold, } \\
\text { copper }\end{array}$ & $\mathrm{T}$ & $2.35^{\mathrm{a}}$ & $\begin{array}{l}\text { Arctic mining nations/ mining } \\
\text { companies }\end{array}$ & $\mathrm{n} / \mathrm{d}$ \\
\hline Oil & $\begin{array}{l}\text { North Slope, Alaska \& Northwest } \\
\text { Arctic region, Russia }\end{array}$ & $\mathrm{T}$ & 17.45 & $\begin{array}{l}\text { Arctic oil producing nations/ oil } \\
\text { companies }\end{array}$ & $\mathrm{n} / \mathrm{d}$ \\
\hline \multicolumn{6}{|c|}{ Direct use value (non-extractive/cultural \& amenity) } \\
\hline $\begin{array}{l}\text { Hunting (cultural/ } \\
\text { identity value) }\end{array}$ & $\begin{array}{l}\text { Polar bear hunt (only estimate } \\
\text { found) }\end{array}$ & $\mathrm{T}, \mathrm{S}$ & 1.30 & $\begin{array}{l}\text { Indigenous adult population of counties } \\
\text { that permit hunting }(n=157,250)^{b}\end{array}$ & 6,547 \\
\hline $\begin{array}{l}\text { Tourism (cruise } \\
\text { ship) }\end{array}$ & $\begin{array}{l}\text { Cruises to Svalbard, Greenland, } \\
\text { Franz Josef, Jan Mayen, Canada }\end{array}$ & $\mathrm{M}, \mathrm{T}, \mathrm{S}$ & 0.02 & Cruise companies & $\mathrm{n} / \mathrm{d}$ \\
\hline \multicolumn{6}{|l|}{ Indirect use value } \\
\hline Climate regulation & Albedo effect \& methane capture & $\mathrm{T}, \mathrm{M}, \mathrm{S}$ & $\begin{array}{c}225.21 \\
(54.61-395.81)\end{array}$ & $\begin{array}{l}\text { Global beneficiaries (minus Arctic } \\
\text { communities to avoid double counting) }\end{array}$ & $\begin{array}{c}30.43 \\
(7.40-53.49)\end{array}$ \\
\hline \multicolumn{6}{|l|}{ Non-use values } \\
\hline $\begin{array}{l}\text { Existence value } \\
\text { (cultural) }\end{array}$ & $\begin{array}{l}\text { Cultural value of reindeer herding } \\
\text { to non-herders }\end{array}$ & $\mathrm{T}$ & $\begin{array}{c}3.20 \\
(2.38-4.02)\end{array}$ & Traditional herding nations ${ }^{c}$ & $\begin{array}{c}24.61 \\
(18.29-30.93)\end{array}$ \\
\hline $\begin{array}{l}\text { Existence value } \\
\text { (iconic species) }\end{array}$ & Beluga whale populations & M & $\begin{array}{c}36.78 \\
(18.51-55.04)\end{array}$ & Arctic nations with beluga populations ${ }^{d}$ & $\begin{array}{c}96.30 \\
(48.46-144.13)\end{array}$ \\
\hline $\begin{array}{l}\text { Existence value } \\
\text { (iconic species) }\end{array}$ & Polar bear populations & $\mathrm{M}, \mathrm{T}$ & 8.99 & Canadian households & $316.80^{\mathrm{e}}$ \\
\hline \multicolumn{6}{|c|}{$\begin{array}{l}\mathrm{T}=\text { terrestrial, } \mathrm{M}=\text { marine, } \mathrm{S}=\text { sea-ice. Where ranges of values are provided in the original studies, these are reported here in brackets (under the mean value) } \\
\text { a Given the large variation in production costs for mining, it was assumed that } 50 \% \text { of mining revenue comprises costs (based on production costs for mining in Alaska). } \\
\text { b Polar bear hunting only permitted in the U.S. (Alaska), Canada and Greenland (PBSG, 2009). } \\
\text { c Sweden, Norway, Finland, Russia are nations with traditional reindeer herding activity. } \\
\text { d The original study (Boxall et al., 2012) estimated marginal utility changes for different levels of beluga whale conservation compared to a current level of } 1000 \text { belugas (classed } \\
\text { as "threatened"). We assume WTP results from Boxall et al. are indicative of existence values for beluga populations among adults in Arctic nations with beluga populations, } \\
\text { which include Canada, Greenland, Norway, Russia and the U.S.. } \\
\text { e The value in the original study (Olar et al., 2011) is in terms of per household 'willingness to pay'. To convert to 'per capita' values, I assumed each household had } 1.5 \text { adults. }\end{array}$} \\
\hline
\end{tabular}


There is data however on the cultural value of the polar bear hunt to Inuit hunters in the Canadian Arctic - a direct-use, non-extractive value. In an assessment of the socio-economic importance of polar bears to Canadian households, Olar et al. (2011) estimated that the cultural benefit of hunting a polar bear comes to about US\$6,547 per adult per year (in 2016 US\$) (estimated by calculating the forgone income from not selling the rights to hunt the polar bear to trophy hunters). This is almost one third of the per capita income for Arctic populations noted above (Larsen \& Fondahl, 2015), a very substantial economic value indeed. Extrapolated to all indigenous adults in countries that allow polar bear hunting (Canada, Greenland and U.S. (PBSG, 2009)), the overall value comes to $\$ 1.30$ bn per year.

The other non-extractive direct use value in this study is for cruise-based tourism. Results indicate that the present value of cruise-based tourism (US\$0.02bn per year) in the Arctic is currently rather small. However, as summer sea-ice melts and cruise ships have greater access to Arctic waters, tourism may increase, although this depends on the Arctic retaining some of its uniqueness as a tourist destination. At present, however, only a few areas for wildlife viewing are accessible, resulting in concentrated traffic to those particular areas and ecosystem degradation from excess trampling of vegetation, noise pollution and litter (Snyder, 2007). This suggests that the carrying capacity of Arctic ecosystems is already being reached, tempering the potential for increases in tourism.

The economic value of climate regulation services provided by the Arctic sea-ice and permafrost surpasses all other values by up to three orders of magnitude. This is because these services are global in nature; the entire planet depends on the climate regulation services provided by the Arctic. In absolute terms, this figure is vast - although distributed over the entire world population, it only amounts to little over $\$ 30$ per capita per year, substantially less than the per capita benefits of subsistence hunting and cultural benefits enjoyed by local populations.

Finally, non-use values are expected to be significant, given that the Arctic is a unique environment with non-substitutable species and ecosystems. Results in Table 1 show that reindeer herding has value to non-herders ranging between $\$ 18.29$ and $\$ 30.93$ per capita per year (using values from Bostedt and Lundgren, 2010). Assuming that residents of countries with reindeer herding activities similarly value traditional herding, the total value is estimated to range 
between $\$ 2.38$ and $\$ 4.02$ billion dollars a year. The existence value of beluga whales is estimated to range between $\$ 48.6$ and $\$ 144$ per adult per year ((based on values in Boxall et al., 2012); the total estimate comes to between $\$ 18.51$ - $\$ 55.04$ per year for all countries with beluga whale populations. Polar bears on the other hand are valued at US\$316.80 per capita per year ( $\$ 475$ per household, assuming 1.5 adults per household), based on values for Canadian households reported in Olar et al. (2011). If we compare the per capita values for polar bears with per capita values for beluga whales, then polar bears values are almost four times the values for beluga whales. Extrapolation over all countries with polar bear populations would yield an overall estimate of the order of $\$ 121$ bn per year. This is a very large value, and should be taken with caution due to fact that it is based on non-primary data. For this reason, the table only reports non-use values for Canadian residents, as it is considered that this value may be inordinately large (especially when compared to other non-use values). Taking existence values for beluga whale, however, it can be concluded that existence values are very substantial and comparable to the economic value of present-day mineral extraction in the Arctic (in making this comparison I am claiming commensurability of different types of values, and issue that is debated in environmental ethics (Aldred, 2005)). Of course, it may not be appropriate to extrapolate benefits estimated for residents of one region or country over the wider populations of Arctic countries, as non-use values may depend on the cultural background and perceptions of the beneficiaries (Hein et al. 2006). Furthermore, as distance from the ES being valued increases, individual valuation of the benefits may decrease (Schaafsma, Brouwer \& Rose, 2012). Hence, these nonuse values may represent an overestimate as distance decay effects have not been considered.

Overall, this preliminary assessment indicates that the annual flow of benefits from key (but by no means, exhaustive) ecosystem services, as well as minerals and oil, provided by the Arctic comes to about $\$ 290$ billion per year (in 2016 US\$); $60 \%$ of this value is accounted for by global climate regulation service provided by permafrost and ice to beneficiaries across the globe. However, the highest per capita values accrue unsurprisingly to indigenous communities, who benefit greatly from subsistence food and cultural capital associated with their interactions with their environment. 


\section{Discussion and Conclusion}

Economic values presented here are for current flows of ecosystem services as well (as some key abiotic resources) provided by the Arctic region. With climate change, however, many of the ecosystem benefits may be lost. For example, it is considered that polar bear populations will decline by about $30 \%$ overall due to climate change (Durner et al. 2009). Although no primary economic non-use values have been generated for polar bears (and hence caution is urged when using this value as noted in Section 3), we can safely assume that members of the public will value the long-term existence of these iconic species at least as much as beluga whales. This implies an annual loss of at least $\$ 96$ per capita per year. Other species that are dependent on sea-ice such as bearded seals are also likely to experience increased mortality due to disappearing habitat (Kovacs et al., 2011), resulting in further losses to human welfare in terms of our valuation of the existence of these species.

Climate change however may also lead to new opportunities. For example, the USGS (2008) estimates that there are $90 \mathrm{bn}$ barrels of recoverable oil in the Arctic, 25\% of which are in Alaska, as well as 44bn barrels of natural gas liquids. In addition, mineral extraction is likely to increase significantly, particularly in Greenland (see Table S6 in Supplementary Material). Greater accessibility and lower risks imply greater profit margins for the oil and mining industry. Furthermore, as sea-ice retreats, fishing grounds that were previously not accessible will open up; warmer temperatures will benefit some existing commercial fish species and lead to northwards migration of fisheries from the south. Shipping routes may also open up; shorter Arctic routes (compared to, for example, the Suez Canal) have the potential to save companies millions in increased savings in time and fuel (Emerson \& Lahn, 2012).

On the other hand, all these opportunities will also potentially result in disruption to ecosystems in the region. For example, one can anticipate overfishing as a result of increased access to Arctic waters. Oil extraction has high environmental costs associated with oil leaks from pipes, oil spills and extensive infrastructure development (Krupnick et al., 2011; AMAP, 2010) as well as from the increased carbon emissions resulting from use of oil. Mining for minerals and metals has very high environmental costs. For example, in an assessment of the potential environmental impacts of the controversial open-pit Kvaefjeld uranium mine in Greenland which is due to initiate operation in 2018 (see Table S6 in Supplementary Material), 
van Leeuwen (2014) concludes that that the tailings (mining waste) will entail an environmental and health hazard regardless of how they are disposed of. Nonetheless, the potential to stimulate the economies in these Northern latitudes may be valuable to local communities with few opportunities (AMAP, 2010), hence robust and extensive regulation and sustainable practices are essential for these potentially expanding industries to minimise negative impacts in the Arctic.

This aim of this short communication was to identify the economic value of ecosystem services provided by Arctic ecosystems, and to highlight the need for more primary data to aid in this process. The data presented in this paper only modestly touch on the full range of benefits currently provided by Arctic ecosystems. Much more primary data on economic values is needed, particularly primary data on economic non-use values. The loss of the Arctic sea-ice and permafrost ecosystems will be irreversible; quantifying the extent of this loss and its impact on our welfare is critical to inform policy-makers, and motivate decisions vis a vis climate change mitigation before Arctic ice disappears completely. 


\section{Acknowledgements}

Many thanks to Johanna Bozuwa and Francesca Audia for contributions to this study. I also acknowledge the PoLAR partnership for supporting my Postdoctoral Research Fellowship (National Science Foundation Grant Number DUE-1239783). I also acknowledge the Earth Institute at Columbia University for supporting my Postdoctoral Fellowship and for support through the Research Assistantship program. I also acknowledge four anonymous reviewers and for extensive comments on this short communication. Finally, I wish to thank all the members of the PoLAR partnership for their support and feedback. 


\section{References:}

Studies used for valuations:

Arnason, R., Kelleher, K. and Willmann, R. (2008) The Sunken Billions: The Economic Justification for Fisheries Reform. Joint publication of the World Bank and the FAO.Washington, DC: Agriculture and Rural Development Department, The World Bank.

Bogoyavlenskiy, D., and Siggner, A. (2004) 'Arctic demography', in: Arctic Human Development. Akureyri: Stefansson Arctic Institute. 27-41

Bostedt, G. and Lundgren, T. (2010) Accounting for cultural heritage-A theoretical and empirical exploration with focus on Swedish reindeer husbandry. Ecological Economics 69.3 (2010): 651-657.

Boxall, P. C., Adamowicz, W. L., Olar, M., West, G. E., \& Cantin, G. (2012). Analysis of the economic benefits associated with the recovery of threatened marine mammal species in the Canadian St. Lawrence Estuary. Marine Policy, 36(1), 189-197.EIA, (2010). "How much does it cost to produce crude oil?" http://www.eia.gov/tools/

EIA (2013) Alaska North Slope Crude Oil Production (Thousand Barrels) Dataset. Available on: http://www.eia.gov/

EIA (2013) Russia. Country Analysis Brief. Last updated March $30^{\text {th }}$ 2013. Available on: http://www.eia.gov/countries/cab.cfm?fips=RS\#note

EIA (2014) Today in Energy. Sept $19^{\text {th }}$ 2014. (Contributors: Alexander Metelitsa and Nicholas Albanese). Available on: http://www.eia.gov/todayinenergy/detail.cfm?id=18051

Fall, J.A. (2014) Subsistence in Alaska: A Year 2012 Update. Division of Subsistence, Alaska Division of Fish and Game.

Goodstein, E., Euskirchen, E., \& Huntington, H. (2010). An initial estimate of the cost of lost climate regulation services due to changes in the Arctic Cryosphere. Washington, DC: Pew Centre.

Haley, S., Klick, M., Szymoniak, N., \& Crow, A. (2011). Observing trends and assessing data for Arctic mining. Polar Geography, 34(1-2), 37-61.

Jorgenssen, F. (2014) 'Arctic shipborne tourism', Association of Arctic Expedition Cruise Operators (AECO). Available on: http://www.imo.org

Loeng, H. (2009) 'Marine Systems', Chapter 9, Arctic Climate Impact Assessment (ACIA)

Olar, M. et al (2011). Evidence of the socio-economic importance of polar bears for Canada. Prepared by ÉcoRessources Consultants, for Environment Canada. 
Program, U. (2014). 2014 National Climate Assessment Full Report. Available on: http://www.energyandclimatechange.org/view/article/537bc46d0cf226e0bdbfef38

PSBGS (2009) National harvest regulations. Available on:

http://pbsg.npolar.no/en/issues/harvest/harvest-regulations.html

PSBGS (2013) Status Table. IUCN/SSC Polar Bear Specialist Group. Available on: See http://pbsg.npolar.no/status

Rothe, A. (2006) A Review of Industrial Hard Rock Mining in Alaska. Halycon Research. Available on: http://northern.org/media-library/document-archive/clean-watermining/mining/a-review-of-industrial-hard-rock-mining-in-alaska/download

Vilhjálmsson, H. and Hoel, A.H. (2004) 'Fisheries and Aquaculture', Chapter 13 Arctic Climate Impact Assessment (ACIA)

Arnason, R., Kelleher, K. and Willmann, R. (2008) The Sunken Billions: The Economic Justification for Fisheries Reform. Joint publication of the World Bank and the FAO.Washington, DC: Agriculture and Rural Development Department, The World Bank.

\section{$\underline{\text { Other references: }}$}

Aldred, J. (2006). Incommensurability and monetary valuation. Land economics, 82(2), 141-161.

AMAP (2010) Assessment 2007: Oil and Gas Activities in the Arctic - Effects and Potential Effects, Volume 1. Arctic Monitoring and Assessment Programme. Oslo: Norway

Armstrong, C. W., Foley, N. S., Tinch, R., \& van den Hove, S. (2012). Services from the deep: Steps towards valuation of deep sea goods and services. Ecosystem Services, 2, 2-13.

Barros, V. R., Field, C. B., Dokke, D. J., Mastrandrea, M. D., Mach, K. J., Bilir, T. E., ... \& Girma, B. (2014). Climate change 2014: impacts, adaptation, and vulnerability. Part B: regional aspects. Contribution of Working Group II to the fifth assessment report of the Intergovernmental Panel on Climate Change.

Bouma, J., Bulte, E., \& van Soest, D. (2008). Trust and cooperation: Social capital and community resource management. Journal of environmental economics and management, 56(2), 155-166.

CAFF 2015. The Economics of Ecosystems and Biodiversity (TEEB) Scoping Study for the Arctic. Conservation of Arctic Flora and Fauna, Akureyri, Iceland. ISBN: 978-9935-431-46-2

CAFF (2013). Arctic Biodiversity Assessment. Status and trends in Arctic biodiversity. Conservation of Arctic Flora and Fauna, Akureyri. 
Coyle, K. O., Eisner, L. B., Mueter, F. J., Pinchuk, A. I., Janout, M. A., Cieciel, K. D., ... \& Andrews, A. G. (2011). Climate change in the Southeastern Bering Sea: impacts on pollock stocks and implications for the oscillating control hypothesis. Fisheries Oceanography, 20(2), 139-156.

Daly, D. (2015). The Concept of Catchment Services in the Context of Water Management and WFD Implementation. Discussion paper. EPA, Dublin, Ireland.

De Groot, R., Brander, L., Van Der Ploeg, S., Costanza, R., Bernard, F., Braat, L., Christie, M., Crossman, N., Ghermandi, A., Hein, L. and Hussain, S., (2012). Global estimates of the value of ecosystems and their services in monetary units. Ecosystem services, 1(1), pp.50-61.

Duarte, C.M., Agustí, S., Wassmann, P., Arrieta, J.M., Alcaraz, M., Coello, A., Marbà, N., Hendriks, I.E., Holding, J., García-Zarandona, I. and Kritzberg, E., (2012). Tipping elements in the Arctic marine ecosystem. Ambio, 41(1), pp.44-55.

Emmerson, C., \& Lahn, G. (2012). Arctic opening: Opportunity and risk in the high north. LLoyd's: London.

EVRI (1997) The Environmental Valuation Reference Inventory. Developed by De Civita, P., Filion, F. \& Frehsof, J. Environment Canada. Available from: https://www.evri.ca/

Gosselin M., M. Levasseur, P. A. Wheeler, R. A. Horner, and B. C. Booth (1997). New measurements of phytoplankton and ice algal production in the Arctic Ocean. Deep-Sea Res. II, 44, 1623-1644.

Hall, C \& Saarin, J. (2008). Polar Tourism: Definitions and Dimensions. University of Cantebury. 1-13.

Hassol, S.J. (2013) Impacts of a Warming Arctic-Arctic Climate Impact Assessment. Arctic Climate Impact Assessment (ACIA), Cambridge, UK: Cambridge University Press.

Huntington, H. P. (2013) Provisioning and Cultural Services. In: CAFF (2013) Arctic Biodiversity Assessment. Status and trends in Arctic biodiversity. Conservation of Arctic Flora and Fauna, Akureyri. Pp592-626

Hein L, van Koppen K, de Groot RS, vanIerland EC (2006) Spatial scales, stakeholders and the valuation of ecosystem services. Ecological Economics, 57:209-228

IPCC (2013) Climate Change 2013: The Physical Science Basis. Contribution of Working Group I to the Fifth Assessment Report of the Intergovernmental Panel on Climate Change [Stocker, T.F., D. Qin, G.-K. Plattner, M. Tignor, S.K. Allen, J. Boschung, A. Nauels, Y. Xia, V. Bex and P.M. Midgley (eds.)].Cambridge University Press, Cambridge, United Kingdom and New York, NY, USA, 1535 pp, doi:10.1017/CBO9781107415324 
IPCC (2007) Climate Change 2007: Impacts, Adaptation and Vulnerability. Contribution of Working Group II to the Fourth Assessment Report of the Intergovernmental Panel on Climate Change, M.L. Parry, O.F. Canziani, J.P. Palutikof, P.J. van der Linden and C.E. Hanson, Eds., Cambridge University Press, Cambridge, UK, 976pp.

Jones, L., Norton, L., Austin, Z., Browne, A.L., Donovan, D., Emmett, B.A., Grabowski, Z.J., Howard, D.C., Jones, J.P.G., Kenter, J.O. and Manley, W., (2016) Stocks and flows of natural and human-derived capital in ecosystem services. Land Use Policy, 52, pp.151-162.

Kovacs, K. M., Lydersen, C., Overland, J. E., \& Moore, S. E. (2011). Impacts of changing seaice conditions on Arctic marine mammals. Marine Biodiversity, 41(1), 181-194.

Krutilla, J. V. (1967). Conservation reconsidered. The American Economic Review, 57(4), 777786.

Laidre, K. L., Stirling, I., Lowry, L. F., Wiig, Ø., Heide-Jørgensen, M. P., \& Ferguson, S. H. (2008). Quantifying the sensitivity of Arctic marine mammals to climate-induced habitat change. Ecological Applications, 18(sp2).

Larsen, J. N., \& Fondahl, G. (Eds.). (2015). Arctic human development report: Regional processes and global linkages. Nordic Council of Ministers.

MA (2005). Ecosystems and Human Well-Being: Synthesis. Millennium Ecosystem Assessment. Island Press, Washington. 155pp.

Mason, M. (2003). Civil liability for oil pollution damage: examining the evolving scope for environmental compensation in the international regime. Marine Policy, 27(1), 1-12.

Pascual, U., Muradian, R., Brander, L., Gómez-Baggethun, E., Martín-López, B., Verma, M., Armsworth, P., Christie, M., Cornelissen, H., Eppink, F. and Farley, J., (2010) The Economics of Valuing Ecosystem Services and Biodiversity. In: Kumar, P. (eds) The Economics of Ecosystems and Biodiversity: Ecological and Economic Foundations. UNEP/Earthprint, p183-256.

Pearce, D. W., Markandya, A., \& Barbier, E. (1989). Blueprint for a green economy (Vol. 1). Earthscan: London

R. Putnam, Making Democracy Work: Civic Traditions in Modern Italy, Princeton University Press, Princeton, 1993.

Schaafsma, M., Brouwer, R., \& Rose, J. (2012). Directional heterogeneity in WTP models for environmental valuation. Ecological economics, 79, 21-31.

Snyder, J. (2007). 'Tourism in the Arctic Regions: the sustainability challenge'. United Nations Environmental Programme. Washington, D.C.

Sundberg, S.,\& Soderqvist, T.(2004).ValueBaseSWE. A valuation study database for environmental change in Sweden. Available at www.beijer.kva.se/valuebase.htm, Beijer 
International Institute of Ecological Economics, The Royal Swedish Academy of Sciences, Stockholm.

Turner, R. K. (2001). 'The place of economic values in environmental valuation'. In: Bateman, I. J., \& Willis, K. G. (eds). Valuing Environmental Preferences: Theory and Practice of the Contingent Valuation Method in the US, EU, and Developing Countries. Oxford University Press on Demand, pp17-41.

Van der Meulen, E. S., Braat, L. C., \& Brils, J. M. (2016). Abiotic flows should be inherent part of ecosystem services classification. Ecosystem Services, 19, 1-5.

Vilhjálmsson, A. \& Hoel, H. (2013) 'Fisheries and Aquaculture.' In: Hassol, S.J. (ed) Impacts of a Warming Arctic-Arctic Climate Impact Assessment, Arctic Climate Impact Assessment (ACIA), Cambridge, UK: Cambridge University Press, pp 692-780

Wang, M., \& Overland, J. E. (2009). A sea ice free summer Arctic within 30 years?. Geophysical Research Letters, 36(7). 